JOURNAL OF LANGUAGE, LITERATURE, AND TEACHING

Vol. 1 No. 3, December 2019, pp. 38 - 49

https://doi.org/10.35529/jllte.v1i3.38-49

\title{
The Development of Character-Education-Based Presentation Evaluation Tool on Indonesian as a General Education Courses Indonesia University of Education
}

\author{
Mochamad Whilky Rizkyanfi \\ Universitas Pendidikan Indonesia \\ Bandung, Indonesia \\ Nuri Novianti Afidah \\ Universitas Pendidikan Indonesia \\ Bandung, Indonesia
}

\begin{abstract}
The number of assignments for each course taken by students in one semester causes students to work their given assignments irresponsibly, without considering the assessment aspects required related to the assignment. One assignment that commonly done inattentively by the student is the presentation, and it applies to every course they have taken that requires a presentation. Based on the concept of eighteen values forming character education, the author compiles the concept of presentation assessment formats, including, discipline, hard work, creative, communicative, reading habit, and responsibilities in which are applied as a basis for assessment consideration adjusted to linguistic assessments. In this study, the authors used a qualitative approach. The authors highlighted that the eighteen values forming character could be adjusted in accordance with the Indonesian speaking skills assessment. Furthermore, the concept was then formulated into ten aspects of presentation evaluation, namely (1) language: formality, effectiveness, politeness; (2) material understanding: readiness, clarity, naturalness in answering questions; (3) slides: clarity, systematics; and (4) performance: politeness and style. This character-forming value can be well utilized as a guideline for presentation assessment formats implemented in a classroom. This tool will have a good impact that in line with the function of character education, which is to develop the basic potential to be kind, think well, and behave well; strengthen and build multicultural national behavior, and increase the sense of competitiveness nationally following in the world civilization.
\end{abstract}

Keywords: presentation assessment, Indonesian Education presentation, character education 
JOURNAL OF LANGUAGE, LITERATURE, AND TEACHING

Vol. 1 No. 3, December 2019, pp. 38 - 49

https://doi.org/10.35529/jllte.v1i3.38-49

\section{INTRODUCTION}

\section{Background of Study}

Indonesian as a general basic course that has been available in higher education level are compulsory courses that can be used to sharpen students' abilities on improving their four basic language skills, including writing, reading, speaking and listening skills. The importance of this course has an impact on concept preparation that must be in line with the objectives of this course.

Indonesian subject has been taught from primary school level until higher education level; it is intended to make Indonesian as a language should have been mastered or at least every Indonesian will have sufficient knowledge regarding the Indonesian language. Unfortunately, the facts occurred in reality that there are lack of students who have the maximum ability to speak Indonesian. Besides, the Indonesian language is crucial to learn in every higher education institutions since at the university every student comes from various regions in Indonesia. Furthermore, the Indonesian language implemented as an official national language and has a great role in arranging scientific papers (thesis, thesis, dissertation, etc.) since it used a very formal Indonesian language that related to language features and grammar. Studying Indonesian for students at university is the same as studying Indonesian subjects in high school, although the discussions at the university level are more specific and in-depth, and most students still want to learn Indonesian so that they can speak the language properly and correctly.

Based on the concepts that have been previously explained, the preparation of the correct syllabus, the methods used in the teaching and learning process, and evaluation tools in Indonesian language courses must accommodate the learning target which enabling students to improve and sharpen their language skills. This is in line with the objectives of Indonesian Language Education courses in the curriculum at the Indonesian University of Education, which is to provide basic knowledge to students about good and correct communication skills, writing, and Indonesian language that following applicable rules and 
JOURNAL OF LANGUAGE, LITERATURE, AND TEACHING

Vol. 1 No. 3, December 2019, pp. 38 - 49

https://doi.org/10.35529/jllte.v1i3.38-49

STBADPIA

画四圆隆友好学院

norms. After attending this lecture, students are expected to be able to write scientific essays and present them in the classroom.

The concept to integrate the importance of Indonesian as a general course is to collaborate with the values contained in character education. Character education is the most pivotal and fundamental thing in order to form an ideal and intelligent human being. Character education has the function and purpose that stated in national education; it is clear that education at every level must be carried out systematically in order to achieve these goals. This is related to the formation of students' character; consequently they will able to compete, be ethical, moral, polite and easily interact with the community.

In the context of Indonesianism, the application of character education is a nonnegotiable necessity. Based on the facts on that fundamentally related to morals, there are many moral deviations that are one of the reasons for delivering character education in the world of Indonesian education that refers to the ideals of the nation. For instance, the number of assignments for each subject taken by a student in one semester causes the student to arrange assignments inattentively, without considering the assessment aspects required in the assignment. One assignment that commonly done inattentively by the student is the presentation, and it applies to every course they have taken that requires a presentation. Based on the concept of eighteen values forming character education, the author compiles the concept of presentation assessment formats, including, discipline, hard work, creative, communicative, reading habit, and responsibilities in which are applied as a basis for assessment consideration adjusted to linguistic assessments. Hopefully, the presentation, that will be collaborated with character education will achieve the nation's educational goals that are intelligent and noble and become full human beings. (Dewi, 2014).

In the context of Indonesianism, the application of character education is a nonnegotiable necessity. Based on the facts on that fundamentally related to morals, there are many moral deviations that are one of the reasons for delivering character education in the world of Indonesian education that refers to the ideals of the nation. For instance, the number of assignments for each subject taken by a student in one semester causes the student to arrange assignments inattentively, without considering the assessment aspects required in the 
JOURNAL OF LANGUAGE, LITERATURE, AND TEACHING

Vol. 1 No. 3, December 2019, pp. 38 - 49

https://doi.org/10.35529/jllte.v1i3.38-49

STBADPIA

画四圆隆友好学院

assignment. One assignment that commonly done inattentively by the student is the presentation, and it applies to every course they have taken that requires a presentation. Based on the concept of eighteen values forming character education, the author compiles the concept of presentation assessment formats, including, discipline, hard work, creative, communicative, reading habit, and responsibilities in which are applied as a basis for assessment consideration adjusted to linguistic assessments. Hopefully, the presentation, that will be collaborated with character education will achieve the nation's educational goals that are intelligent and noble and become full human beings. (Dewi, 2014).

\section{Research Questions}

As a basis for reviewing the problems contained in this paper, the following are the research questions raised by the author:

1. What are the considerations for evaluating the presentation of Indonesian Language courses at UPI?

2. How do students achieve the results after using the concept of assessment presentation that conceptualizes character education?

\section{Research Purpose}

Based on the formulation of the problem, the purposes of this research are elaborated as follows:

1. to describe the things that should be considered in evaluating the presentation,

2. to describe the results achieved by students after using the concept of assessment presentations that conceptualize character education.

\section{Research Method}

This study uses the observation method conducted during presentation learning which is supported by interviewing students. 
JOURNAL OF LANGUAGE, LITERATURE, AND TEACHING

Vol. 1 No. 3, December 2019, pp. 38 - 49

https://doi.org/10.35529/jllte.v1i3.38-49

\section{DISCUSSION}

\section{Presentation Skill}

Abidin et al. (2010) explain that a presentation is a medium of communication to convey a message by explaining or describing a material systematically and hopes that it will be effective both for the presenter and the audience. In the Kamus Besar Bahasa Indonesia, it is stated that the presentation has the meaning of "giving, pronunciation, speech (on accepting a position, introduction of someone to someone usually higher position), presentation, or performance (about plays, films, etc.).

The two aforementioned quotes showed that presentation is a communication process carried out by the communicant with the aim of conveying the message to the audience by explaining. The process of that communication is one aspect of language skills (speaking). The presentation as a communication activity certainly has a purpose. The purpose of the presentation can be seen from various points of view. The purpose of the presentation in terms of the type of presentation can be elaborated as follows:

1. Presentations for scientific activities that have the purpose of conveying information, findings, analysis, etc.

2. Presentation to sell something. This presentation is usually done in association with a business to entice and attract the audience to accept what is being offered becomes something that the audience needs.

3. Presentations for education. This presentation was conducted in the context of teaching and learning processes that are formal or non-normal. This presentation is more in the form of teaching / educating, lecturing, guiding, etc.

4. Presentation for program preparation. It has a purpose to find out what programs will be carried out by the group or organization during one work program period.

5. Presentations to add insight. This presentation is presented in an informal situation, as it is typically used to present material related to human interest.

Beside differentiate from the type, in general, the presentation aims to:

1. delivery of information,

2. entertain the audience, 
JOURNAL OF LANGUAGE, LITERATURE, AND TEACHING

Vol. 1 No. 3, December 2019, pp. 38 - 49

https://doi.org/10.35529/jllte.v1i3.38-49

STBADPIA

3. touch the emotions of the audience,

4. motivate the audience to act in a certain way.

To conclude, the purpose of the presentation is determined by what type of presentation will be conducted. The purpose of the educational presentation is not the same as the purpose of presentation in business, but in general, the purpose of the presentation is the same, namely to convey a message to the audience consequently the audience is affected and then change their behaviour.

\section{Character Education Concept}

Character education is a system of implanting character values to school members which include components of knowledge, awareness or will, and actions to carry out these values, both towards Almighty God, oneself, others, the environment, and nationality to be our people. The character education in schools, all components (stakeholders) must be involved, including the components of education itself, namely the contents of the curriculum, learning and assessment processes, the quality of relationships, the handling or management of subjects, school management, implementation of activities or co-curricular activities , empowered infrastructure, financing, and the work ethic of all citizens and the school environment.

Character education is fundamentally aimed to form a strong, competitive, noble, moral, tolerant, mutual cooperation, patriotic-spirited, dynamic-developing, science-and-technologyoriented nation, all of which are implanted with faith and devotion to Almighty God based on Pancasila (Indonesian National Foundation).

Character education has several functions as follows:

1. developing person in accordance to the basic potential of human being such as kind, think well, and behave well,

2. strengthen and build multicultural national behaviour,

3. enhance the nation's competitive civilization in the world association. 
JOURNAL OF LANGUAGE, LITERATURE, AND TEACHING

Vol. 1 No. 3, December 2019, pp. 38 - 49

https://doi.org/10.35529/jllte.v1i3.38-49

雪洲图際友好学院

Character education is carried out through a variety of media that include families, educational units, civil society, political communities, governments, businesses, and mass media.

Character Education Values

Table 1 Character Education Values Description

\begin{tabular}{|c|c|}
\hline Value & Description \\
\hline 1. Religious. & $\begin{array}{l}\text { Obedient attitudes and behaviours in implementing religious } \\
\text { teachings, being tolerant of other religious practices, and living in } \\
\text { harmony with followers of other religions. }\end{array}$ \\
\hline 2. Honesty. & $\begin{array}{l}\text { The Behaviour that is based on efforts to make himself as a person } \\
\text { who can always be trusted in words, actions, and work. }\end{array}$ \\
\hline 3. Tolerance. & $\begin{array}{l}\text { The attitudes and actions that respect differences in religion, } \\
\text { ethnicity, ethnicity, opinions, attitudes, and actions of others that are } \\
\text { different from him. }\end{array}$ \\
\hline 4. Discipline. & $\begin{array}{l}\text { The ctions that show orderly behavior and comply with various rules } \\
\text { and regulations. }\end{array}$ \\
\hline 5. Hard Work. & $\begin{array}{l}\text { The Behavior that shows earnest effort in overcoming various } \\
\text { learning barriers and assignments, and completing tasks as well as } \\
\text { possible. }\end{array}$ \\
\hline 6. Creative. & $\begin{array}{l}\text { The way of thinking to do something or to produce a new way or } \\
\text { result from something they already have. }\end{array}$ \\
\hline 7. Independent. & $\begin{array}{l}\text { The attitudes and behaviors that are not easy depend on others in } \\
\text { completing tasks. }\end{array}$ \\
\hline 8. Democratic. & $\begin{array}{l}\text { The way of thinking, behaving, and acting that values the rights and } \\
\text { obligations of himself and others. }\end{array}$ \\
\hline 9. Curiosity. & $\begin{array}{l}\text { The attitudes and actions that always strive to find out more deeply } \\
\text { and extensively from something that is learned, seen, and heard. }\end{array}$ \\
\hline 10. National Spirit. & $\begin{array}{l}\text { A way of thinking, acting and having insight that places the interests } \\
\text { of the nation and state above the self and group interests. }\end{array}$ \\
\hline 11. Love the & Ways to think, behave and act that show loyalty, care and high \\
\hline
\end{tabular}


JOURNAL OF LANGUAGE, LITERATURE, AND TEACHING

Vol. 1 No. 3, December 2019, pp. 38 - 49

https://doi.org/10.35529/jllte.v1i3.38-49

STBADPIA

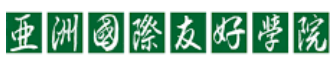

\begin{tabular}{|l|l|}
\hline \hline Motherland. & $\begin{array}{l}\text { respect for the language, physical environment, social, cultural, } \\
\text { economic, and national politics. }\end{array}$ \\
\hline $\begin{array}{l}\text { 12. Appreciating } \\
\text { Achievement. }\end{array}$ & $\begin{array}{l}\text { The attitudes and actions that encourage him to produce something } \\
\text { that is useful for society, and recognize, and respect the success of } \\
\text { others. }\end{array}$ \\
\hline $\begin{array}{l}\text { 13. Friendly / } \\
\text { Communicative. }\end{array}$ & $\begin{array}{l}\text { The actions that show pleasure in talking, hanging out, and working } \\
\text { with others. }\end{array}$ \\
\hline 14. Peaceful Love. & $\begin{array}{l}\text { The attitudes, words, and actions that cause others to feel happy and } \\
\text { safe in his presence. }\end{array}$ \\
\hline 15. Likes to read. & $\begin{array}{l}\text { The habit of providing time to read various readings that provide } \\
\text { virtue for him. }\end{array}$ \\
\hline 16. Care for the & $\begin{array}{l}\text { The attitudes and actions that always try to prevent damage to the } \\
\text { surrounding natural environment and develop efforts to repair natural } \\
\text { damage that has already occurred. }\end{array}$ \\
\hline 17. Social Care. & $\begin{array}{l}\text { The attitudes and actions that always want to provide assistance to } \\
\text { others in need. }\end{array}$ \\
\hline 18. Responsibility. & $\begin{array}{l}\text { The attitude and behavior of a person to carry out their duties and } \\
\text { obligations, which they should do, towards themselves, society, the } \\
\text { environment (natural, social, and cultural), country and Almighty } \\
\text { God. }\end{array}$ \\
\hline
\end{tabular}

\section{General Principles of Evaluation in a Lesson}

The evaluation principles in a lesson are required as a guideline in the procedure of developing evaluation since it contribution to the assessment to improve learning which is partly determined by the principles that underlie its development and use. In connection with the principles of the assessment, Gronlund (1985) proposed six principles of assessment which elaborate the test of learning outcomes should:

1) measure the learning outcomes that have been clearly determined and in accordance with the learning objectives,

2) measuring a representative sample of learning outcomes and materials covered in teaching, 
JOURNAL OF LANGUAGE, LITERATURE, AND TEACHING

Vol. 1 No. 3, December 2019, pp. 38 - 49

https://doi.org/10.35529/jllte.v1i3.38-49

STBADPIA

更洲圆際友好学院

3) includes the types of questions/questions that are most suitable for measuring desired learning outcomes,

4) planned to make sure the results are in accordance with those that will be used specifically,

5) made with maximum reliability and must be interpreted carefully, and

6) used to improve learning outcomes.

In line with the mentioned opinion above, Sujana (1990) argued that the assessment of learning outcomes should be (a) designed to assure the abilities to be assessed, assessment materials, assessment tools and interpretation of assessment results, (b) become an integral part of the teaching and learning process, (c) to ensure the results are objective, the assessment must use various assessment tools and are comprehensive in nature, (d) followed by the follow-up.

Measurement, assessment and evaluation are hierarchical activities. This regard means that the three activities concerning the teaching and learning process cannot be separated from one another and in the implementation must be carried out sequentially. According to Arikunto (2004: 1) evaluation is an activity to gather information about the something is perfectly workings, which then the information is used to determine appropriate alternatives in making decisions. In the field of education, evaluation, as stated by Gronlund (1985), is a systematic process of gathering, analyzing, and interpreting information to determine the extent to which learning objectives have been achieved by students.

\section{Presentation Assessment Conceptualized on the Value of Character Education}

\section{Considerations on Presentation Assessment Conceptualized on the Value of}

\section{Character Education}

Based on the eighteen values of character education that have been presented in the previous section, the authors attempt to assess the students' presentation skills in Indonesian that are formulated to be applied easily and simply. This assessment certainly has gone some consideration of speaking skills that can be incorporated into several aspects of the character education values. 


\section{JOURNAL OF LANGUAGE, LITERATURE, AND TEACHING}

Vol. 1 No. 3, December 2019, pp. 38 - 49

https://doi.org/10.35529/jllte.v1i3.38-49

The concept was formulated into ten aspects of presentation evaluation, namely (1) language: formality, effectiveness, politeness; (2) material understanding: readiness, clarity, naturalness in answering questions; (3) slides: clarity, systematics; and (4) performance: politeness and style. The following is an example of evaluating the presentation concept on the character-forming value.

Table 2 Presentation Assessment Conceptualized on the Value of Character Education

\begin{tabular}{|c|c|c|c|c|c|c|c|c|c|c|c|c|c|}
\hline \multirow[b]{3}{*}{ No. } & \multirow[b]{3}{*}{$\begin{array}{c}\text { STU } \\
\text { DEN } \\
\text { TS } \\
\text { ID }\end{array}$} & \multirow[b]{3}{*}{ NAME } & \multicolumn{10}{|c|}{ PRESENTATION } & \multirow[b]{3}{*}{$\begin{array}{c}\text { TOTAL } \\
\text { PRESENTAT } \\
\text { ION GRADE }\end{array}$} \\
\hline & & & \multicolumn{3}{|c|}{ LANGUAGE } & \multicolumn{3}{|c|}{ MATERIAL MASTERY } & \multicolumn{2}{|c|}{ SLIDE } & \multicolumn{2}{|c|}{ PERFORMANCE } & \\
\hline & & & $\begin{array}{c}\text { FORMAL } \\
\text { (kosakata) } \\
0 / 1 / 2\end{array}$ & $\begin{array}{c}\text { SENTAN } \\
\text { CE } \\
\text { (correct/ } \\
\text { effective } \\
\text { ) } 0 / 1 / 2\end{array}$ & $\begin{array}{c}\text { POLITEN } \\
\text { ESS (in } \\
\text { words) } \\
0 / 1 / 2\end{array}$ & $\begin{array}{c}\text { NOT A } \\
\text { TEXTBO } \\
\text { OK } \\
\text { /reading } \\
\text { the } \\
\text { whole } \\
\text { slides } \\
0 / 1 / 2\end{array}$ & $\begin{array}{c}\text { CLEAR } \\
\text { (easily to } \\
\text { understan } \\
\text { d) } 0 / 1 / 2\end{array}$ & $\begin{array}{c}\text { NATUR } \\
\text { ALNESS } \\
\text { (in } \\
\text { answeri } \\
\text { ng } \\
\text { questio } \\
\text { ns) } \\
0 / 1 / 2\end{array}$ & $\begin{array}{c}\mathrm{JCL} \\
\mathrm{EA} \\
\mathrm{R} \\
0 / 1 \\
\mathrm{~T} \\
/ 2\end{array}$ & $\begin{array}{c}\text { SYSTEM } \\
\text { ATIC } \\
0 / 1 / 2\end{array}$ & $\begin{array}{c}\text { GEST } \\
\text { URES } \\
\text { (ex/ } \\
\text { leanin } \\
\text { g to } \\
\text { the } \\
\text { wall, } \\
\text { crossi } \\
\text { ng } \\
\text { arm, } \\
\text { etc.) } \\
0 / 1 / 2\end{array}$ & $\begin{array}{c}\text { POLITENES } \\
\mathbf{S} \text { (did not } \\
\text { pay } \\
\text { attention } \\
\text { while } \\
\text { discussion) } \\
0 / 1 / 2\end{array}$ & \\
\hline 1 & & & & & & & & & & & & & \\
\hline 2 & & & & & & & & & & & & & \\
\hline 3 & & & & & & & & & & & & & \\
\hline 4 & & & & & & & & & & & & & \\
\hline
\end{tabular}

In the form of the presentation assessment, the authors adjust the assessment indicators into the value of character education. The explanations are elaborated below:

a. Language (standard, sentence and polite)

The value of character education that appears in this assessment indicator is discipline and reading habit, specifically discipline in applying the rules that exist in the assessment system as well as the responsibility given to him/her individually.

b. Material Mastery (not a textbook, clear, and correct)

The value of character education that appears in this assessment indicator is honest, hard work, independent, curiosity, and reading habit. Honest with the material to be conveyed, hard work in terms of presenting the best presentations as possible, independent with presentation material that becomes his/her individual assignment, curiosity, and reading habit that shows in delivering material, maximum reading results to the audience. 
JOURNAL OF LANGUAGE, LITERATURE, AND TEACHING

Vol. 1 No. 3, December 2019, pp. 38 - 49

https://doi.org/10.35529/jllte.v1i3.38-49

STBADPIA

画四圆隆友好学院

c. Slides (clear and systematic)

The value of character education that appears in this assessment indicator is creative. Be creative in making slides to be interesting to the audience.

d. Performance (style and manners)

The value of character education that appears in this assessment indicator is friendly/communicative. Communicative so that the presentation runs attractively and stimulates the audience to discuss.

\section{The results of the value obtained by students}

In terms of application, students make presentations with responsibilities, read first what they are presenting, whether it is communicative or not. Students are not inattentively preparing a presentation because all aspects of the assessment have been notified in advance. Presentations made to be very active, creative, and disciplined as expected by the authors. The response of the students was so positive because they thought that this method could be done because it forced them to perform well and use good and correct Indonesian. This, of course, becomes a challenge for students themselves to make a good presentation so that the grades they will get will be good as well. However, on the contrary, if the students present a bad presentation, their assessment will have a bad impact on themselves.

\section{CONCLUSION}

This character forming value can be utilized well as a guideline in the formation of presentation assessment forms conducted in class. This will have a good impact in line with the function of character education, which is to develop the basic potential to be kind, think well, and behave well; strengthen and build multicultural national behavior; and increase the competitive national civilization in the world. 
JOURNAL OF LANGUAGE, LITERATURE, AND TEACHING

Vol. 1 No. 3, December 2019, pp. 38 - 49

https://doi.org/10.35529/jllte.v1i3.38-49

STBADPIA

\section{REFERENCES}

Abidin, Yunus dkk. (2010). Kemampuan Berbahasa Indonesia di Perguruan Tinggi. Bandung: CV Maulana Media Grafika.

Anonim. (2012). "Pendidikan Karakter". [Online]. Tersedia: //pndkarakter.wordpress.com/category/pilar-pilar-pendidikan-karakter/ [30 Juni 2018]

Arikunto, Suharisimi. (2012). Dasar-dasar Evaluasi Pendidikan (Edisi kedua). Jakarta: PT Bumi Aksara.

Dewi, Renita Rosalinda. (2014). "Konsep dasar Pendidikan Karakter". [Online]. Tersedia: http://rinitarosalinda.blogspot.com/2014/04/konsep-dasar-pendidikan-karakter.html [30 Juni 2108]

Gronlund, Norman, E. 1985. Measurement and Evaluation in Teaching, Fifth Edition. New York : McMillan Publising.

Husaini, Ahmad. (2012). “Tujuan dan Fungsi Pendidikan Karakter”. [Online]. Tersedia: http://pndkarakter.wordpress.com. [30 Juni 2018]

Sujana, Nana. 1990. Penilaian Hasil Proses Belajar Mengajar. Bandung: PT Remaja Rosdakarya.

Zuchdi, Darmiyati. (2012). "Implementasi Pendidikan Karakter di Perguruan Tinggi”.[Online].Tersedia: http://phitry-kawaii.blogspot.com. [1 Juli 2018]. 